\title{
An Uncommon Case of Lichen Spinulosus in an Adult Patient Clinically Mmimicking Folliculotropic Mycosis Fungoides
}

\author{
Maryam Aghighi ${ }^{1}$, Tatsiana Pukhalskaya ${ }^{2}$, Sylvana Brickley ${ }^{3}$, Bruce Smoller ${ }^{4}$ \\ 1. Pathology, Saint Barnabas Medical Center, Robert Wood Johnson Barnabas Health, Livingston, USA 2. Pathology, \\ University of Rochester Medical Center, Rochester, USA 3. Dermatology, University of Rochester Medical Center, \\ Rochester, USA 4. Pathology and Dermatology, University of Rochester School of Medicine and Dentistry, Rochester, \\ USA
}

Corresponding author: Maryam Aghighi, maryam.aghighi@rwjbh.org

\begin{abstract}
Lichen spinulosus (LS) is an uncommon skin condition mostly in children and adolescents but uncommon in adults. It presents as a group of hypopigmented or skin-colored follicular papules and keratotic spines with a sandpaper-like appearance. There is a lymphohistiocytic infiltrate in the dermis centered around hair follicles. We present a rare case of LS in a 52-year-old woman with a rough, bumpy, itchy rash affecting the trunk and extremities. Her rash consisted of clusters of hyperkeratotic follicular-based spiny papules. Histologic sections demonstrated several dilated hair follicles filled with keratotic plugs surrounded by a dense perifollicular lymphohistiocytic infiltrate, particularly at the level of the infundibula, that extended into the follicular epithelium.
\end{abstract}

Categories: Dermatology, Pathology

Keywords: lichen spinulosus, perifollicular lymphohistiocytic infiltrate

\section{Introduction}

Lichen spinulosus (LS) is a rare dermatosis with an unknown etiology. It is most common in children and adolescents but occurs very rarely in adults [1]. It may have a genetic predisposition or be associated with gold, arsphenamine, thallium, diphtheria toxin, atopy, lithium therapy, Crohn's disease, Hodgkin disease, human immunodeficiency virus (HIV) or alcoholism [2-5]. Additionally, vitamin A deficiency is associated with LS [1]. It presents as a group of 2-5 cm hypopigmented or skin-colored follicular papules and keratotic spines with a sandpaper-like appearance [6]. The lesions usually erupt on various regions of the skin and remain for weeks to months. The histologic findings consist of a lymphohistiocytic infiltrate in the dermis centered around hair follicles. We report an uncommon case of LS occurring in an adult patient in whom the main clinical concern was for folliculotropic mycosis fungoides.

Received 05/05/2020

Review began 05/16/2020 Review ended 06/07/2020 Published 06/12/2020

() Copyright 2020 Aghighi et al. This is an open access article distributed under the terms of the Creative Commons Attribution License CC-BY 4.0., which permits unrestricted use, distribution, and reproduction in any medium, provided the original author and source are credited.

\section{Case Presentation}

A 52-year-old female presented to the dermatology clinic with a rough, bumpy minimally itchy rash affecting the lower back, bilateral arms, abdomen, anterior thighs, and shins. She had a history of hypertension, hypothyroidism, vitamin D deficiency, vitreous hemorrhage, bilateral carotid artery dissection, dissecting hemorrhage of the left vertebral artery, cardiomyopathy, and subarachnoid hemorrhage. The cutaneous eruption had been present for about a year. She had not used any topical steroids or any other treatment before her dermatologic visit. She had no personal or family history of skin cancer. She reported no smoking history or alcohol consumption. She did not have any fevers, chills, weight loss, nausea, vomiting, diarrhea, or mouth sores. Her eruption consisted of clusters of hyperkeratotic follicular based spiny papules and scattered in a widespread distribution on the anterior bilateral thighs, lower back, abdomen, and bilateral forearms as demonstrated in Figure 1. 


\section{Cureus}

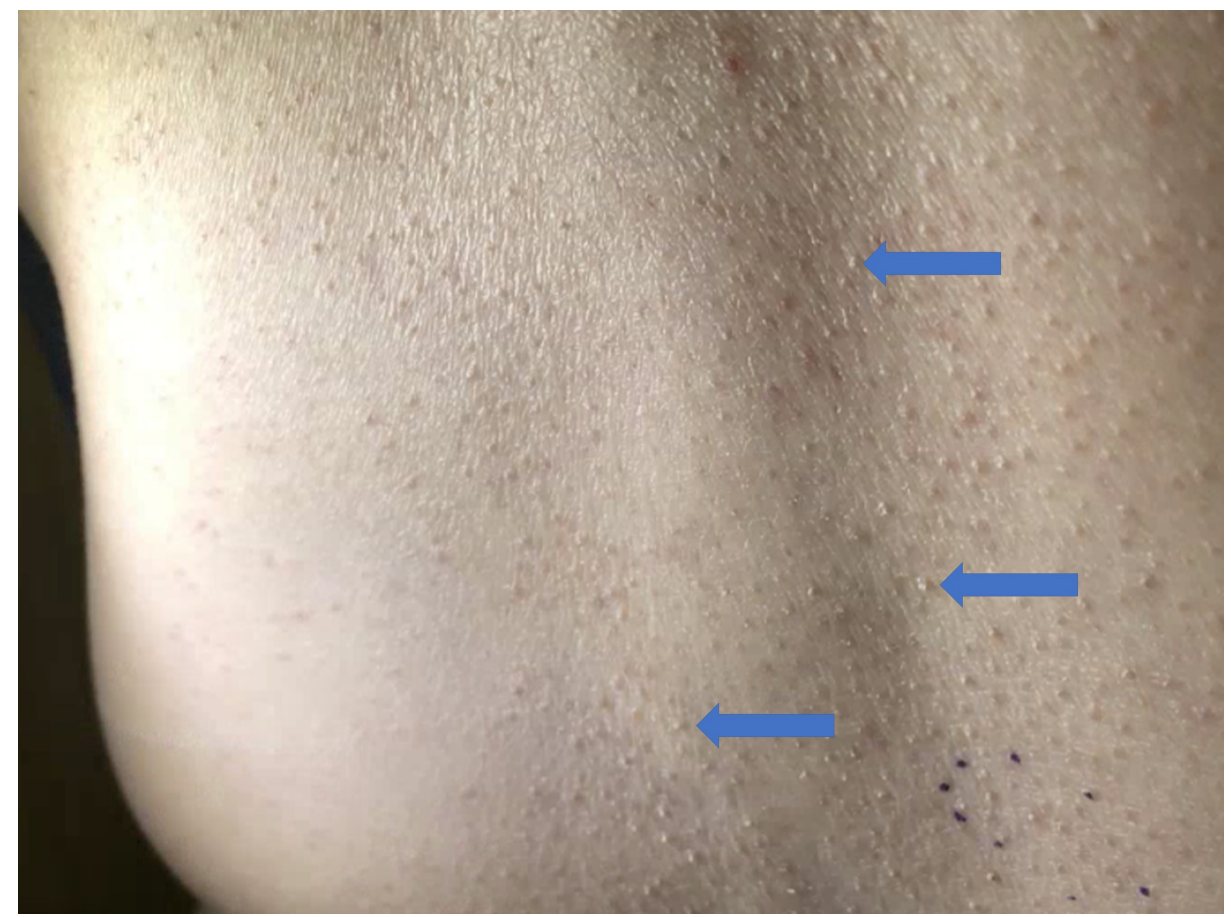

FIGURE 1: Clinical presentation of lichen spinulosus (LS): clusters of hyperkeratotic follicular based spiny papules on the lower back of the patient (blue arrows)

Vitamin A supplementation (10,000 units daily for two months) for slight hypovitaminosis A (level 30 $\mathrm{mgc} / \mathrm{dL}$, reference range $38-98 \mathrm{mcg} / \mathrm{dL}$ ) led to no lesion improvement. Twice daily Urea $20 \%$ cream was added. A shave biopsy was performed with clinical concern for folliculotropic mycosis fungoides, scurvy and LS.

Histologic sections demonstrated several dilated hair follicles filled with keratotic plugs and surrounded by dense perifollicular lymphohistiocytic inflammatory infiltrates, particularly at the level of the infundibula. The lymphocytic infiltrate extended into the follicular epithelium with concomitant spongiosis. There was mild perifollicular fibrosis and noticeable atrophy of the sebaceous glands as illustrated in Figures 2-4. No atypical lymphocytes or epidermotropism were identified. These findings are those classically described in LS. Given the clinical concerns, a T-cell gene rearrangement study was performed and failed to demonstrate T-cell clonality. 


\section{Cureus}

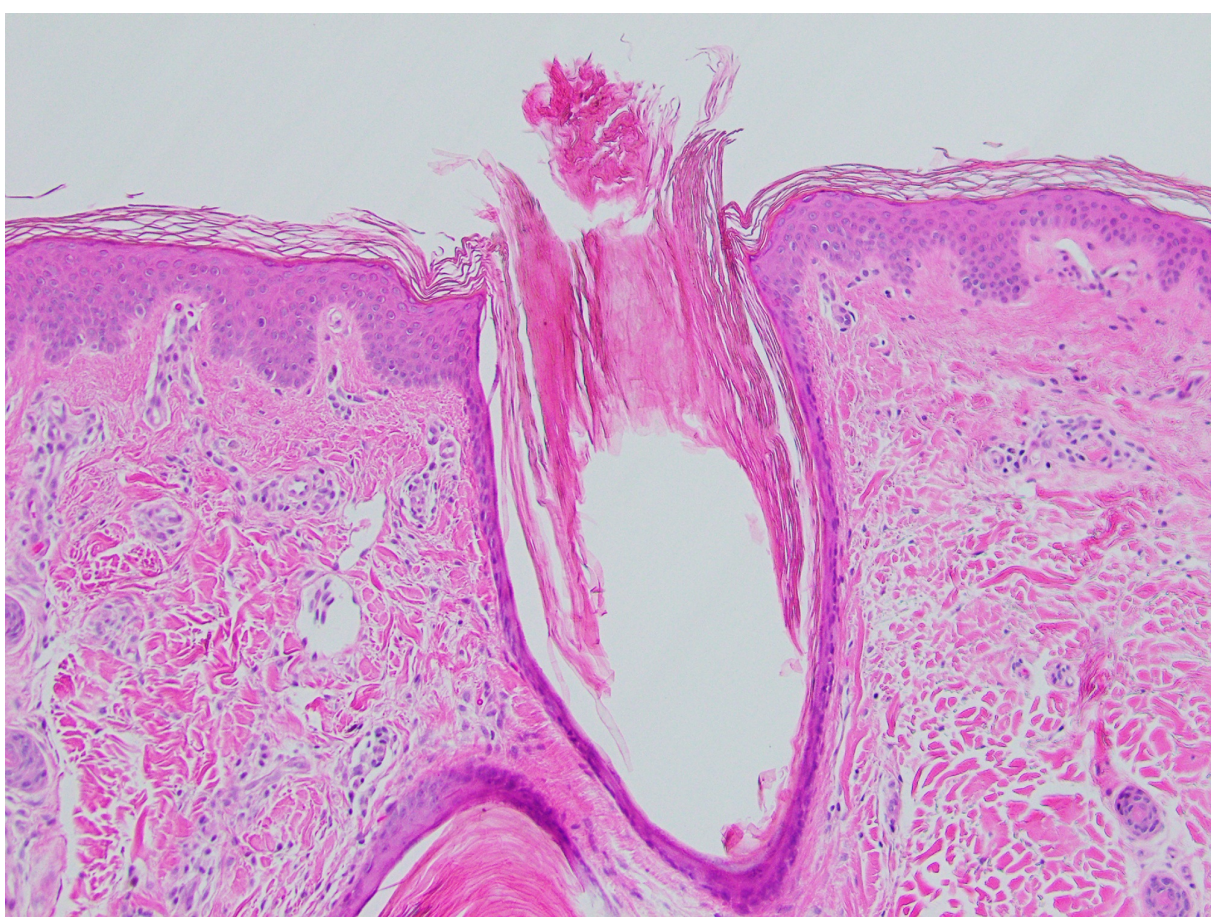

FIGURE 2: Hematoxylin and eosin (H\&E) staining (100x) identifying dilated hair follicle filled with keratotic plugs surrounded by dense perifollicular lymphohistiocytic inflammatory infiltrates

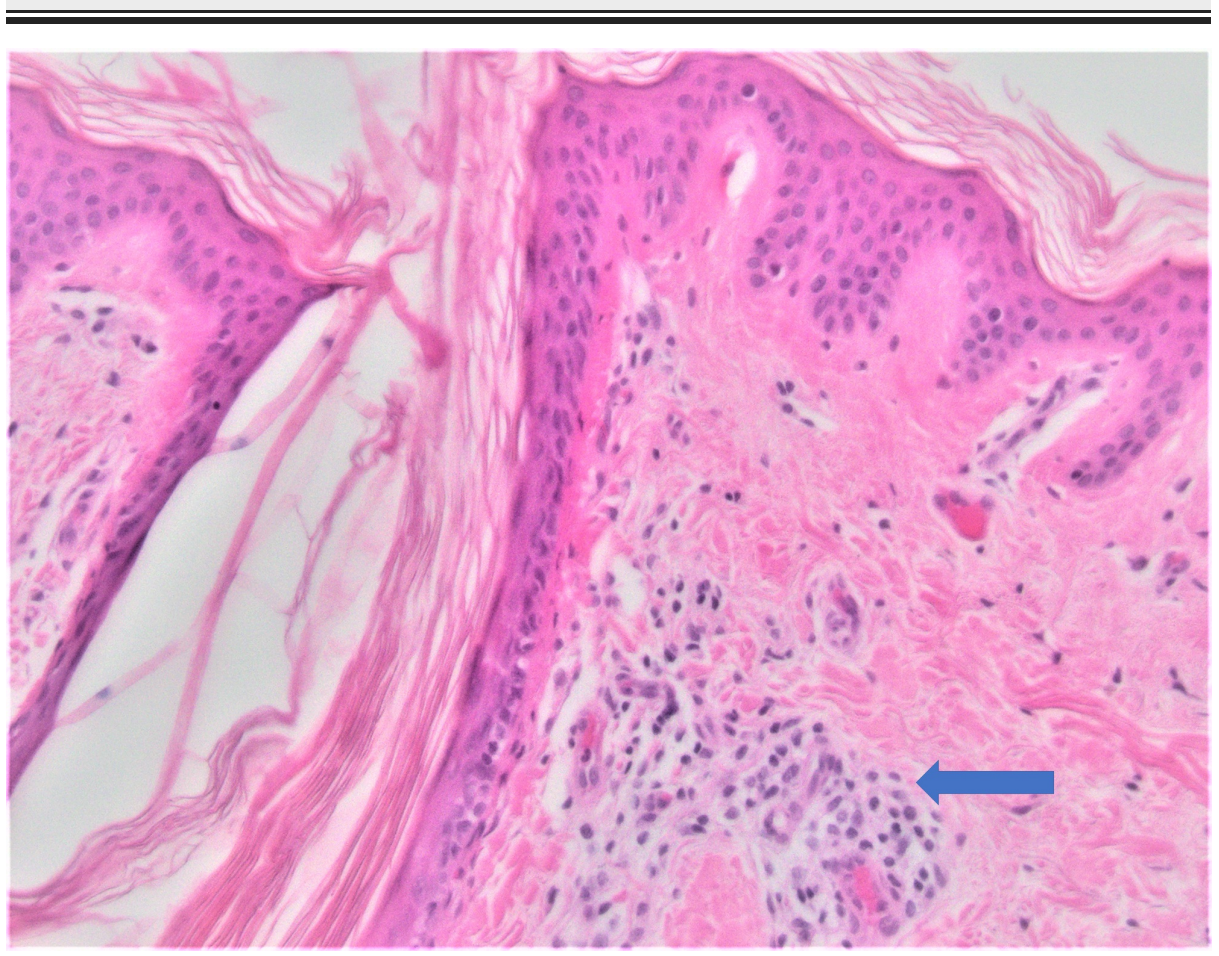

FIGURE 3: Hematoxylin and eosin (H\&E) staining (200x) identifying lymphohistiocytic inflammatory infiltrates around the hair follicle (blue arrow) 


\section{Cureus}

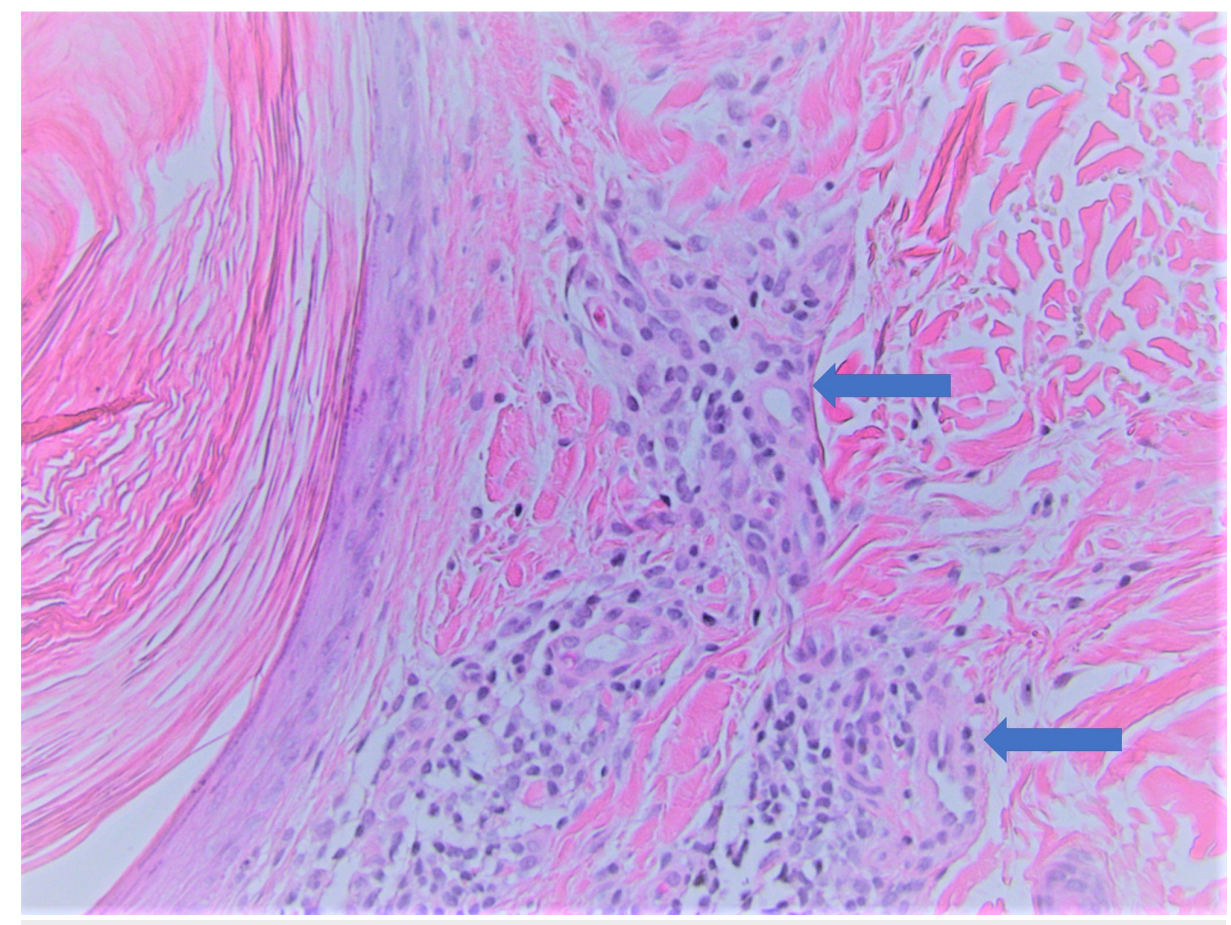

FIGURE 4: Hematoxylin and eosin (H\&E) staining (200x) identifying lymphohistiocytic inflammatory infiltrates around the hair follicle (blue arrows)

\section{Discussion}

LS is a rare dermatosis similar to keratosis pilaris more commonly observed in children and young adults and occurs mostly in male patients. It is rarely observed in adults and elderly patients. Previously, a few cases of LS have been reported in the literature as summarized in Table 1. 


\section{Cureus}

\begin{tabular}{|c|c|c|c|c|}
\hline Authors & $\begin{array}{l}\text { Publication } \\
\text { year }\end{array}$ & $\begin{array}{l}\text { Number of cases and } \\
\text { gender }\end{array}$ & Age & Locations \\
\hline $\begin{array}{l}\text { Al Hawsawi et al. } \\
\text { [6] }\end{array}$ & 2015 & $1 \mathrm{M}$ & 12 & Lower back \\
\hline Uehara et al. [7] & 2015 & $1 \mathrm{M}$ & 69 & Trunk and limbs \\
\hline Litao et al. [8] & 2014 & $1 \mathrm{~F}$ & 7 & Trunk, extremities, hands and face \\
\hline $\begin{array}{l}\text { Sobjanek et al. } \\
\text { [9] }\end{array}$ & 2014 & $1 \mathrm{M}$ & 8 & Knees and shins \\
\hline $\begin{array}{l}\text { Venkatesh et al. } \\
\text { [10] }\end{array}$ & 2012 & $1 \mathrm{M}$ & 4 & $\begin{array}{l}\text { Forehead, neck, abdomen, back, hips, groin and extensor } \\
\text { extremities }\end{array}$ \\
\hline Seo et al. [11] & 2009 & $1 \mathrm{~F}$ & 50 & \\
\hline $\begin{array}{l}\text { Kabashıma et al. } \\
\text { [3] }\end{array}$ & 2008 & $1 \mathrm{M}$ & 59 & Forehead \\
\hline Kim et al. [12] & 2008 & $1 \mathrm{M}$ & 7 & Submental area \\
\hline Oh et al. [13] & 2005 & $1 \mathrm{M}$ & 7 & Both elbows and knees \\
\hline Kim et al. [14] & 2001 & $1 \mathrm{M}$ & 8 & \\
\hline Mittal et al. [15] & 1997 & $1 \mathrm{~F}$ & 8 & Neck, trunk, buttocks and extensors of limbs \\
\hline Kano et al. [16] & 1995 & $1 \mathrm{~F}$ & 61 & $\begin{array}{l}\text { Back, Intertriginous areas of groin, inframammary and left } \\
\text { axilla }\end{array}$ \\
\hline Cohen et al. [2] & 1991 & $1 \mathrm{M}$ & 31 & Face and trunk \\
\hline Friedman [1] & 1990 & $14 \mathrm{M}, 21 \mathrm{~F}$ & $\begin{array}{l}17.8 \pm \\
9.5\end{array}$ & Arms and legs, back, chest, face and neck \\
\hline Tuyp et al. [17] & 1984 & $1 \mathrm{M}$ & 15 & Knees, elbows and lower legs \\
\hline
\end{tabular}

\section{TABLE 1: Previously reported LS cases}

LS shares some clinical and histologic similarity to folliculotropic mycosis fungoides, which may also present with an acne-like eruption and a peri-follicular lymphocytic infiltrate [18]. As in our case wherein, the eruption was longstanding, clinical, histological, and molecular observations may be required to discriminate LS from this variant of mycosis fungoides. Lymphocyte atypia, follicular epidermotropism, and evidence for T-cell receptor gene rearrangements may be used to make this distinction. None of these findings were observed in the current case.

Topical keratolytics and emollients including salicylic acid, vitamin A, tretinoin, tacalcitol, adapalene, and urea are commonly used to treat LS [4,7-8,19-20]. If left untreated, the lesions may resolve on their own after a few weeks to months [10]. For patients with an underlying problem, treatment of the disease may improve LS [3]. Additionally, lesion recurrence has been reported [4].

\section{Conclusions}

LS is a less common skin dermatosis which rarely arises in adult patients. Clinical examination, histological evaluation, and molecular studies may be required to differentiate LS from other entities such as folliculotropic mycosis fungoides.

\section{Additional Information}

\section{Disclosures}

Human subjects: Consent was obtained by all participants in this study. Conflicts of interest: In compliance with the ICMJE uniform disclosure form, all authors declare the following: Payment/services info: All authors have declared that no financial support was received from any organization for the submitted work. Financial relationships: All authors have declared that they have no financial 
relationships at present or within the previous three years with any organizations that might have an interest in the submitted work. Other relationships: All authors have declared that there are no other relationships or activities that could appear to have influenced the submitted work.

\section{References}

1. Friedman SJ: Lichen spinulosus: clinicopathologic review of thirty-five cases . J Am Acad Dermatol. 1990, 22:261-264. 10.1016/0190-9622(90)70035-G

2. Cohen SJ, Dicken CH: Generalized lichen spinulosus in an HIV-positive man . J Am Acad Dermatol. 1991, 25:116-118. 10.1016/S0190-9622(08)80503-8

3. Kabashima R, Sugita K, Kabashima K, Nakamura M, Tokura Y: Lichen spinulosus in an alcoholic patient. Acta Derm Venereol. 2009, 89:311-312. 10.2340/00015555-0600

4. Tilly JJ, Drolet BA, Esterly NB: Lichenoid eruptions in children. J Am Acad Dermatol. 2004, 51:606-624. 10.1016/j.jaad.2003.12.012

5. Boyd AS: Lichen spinulosus: case report and overview. Cutis. 1989, 43:557-560.

6. Al Hawsawi K, Almehmadi K, Alraddadi B, Aljuhani O: Lichen spinulosus: case report and review of literatures. J Health Sci. 2015, 5:20-22. 10.5923/s.health.201501.07

7. Uehara A, Abe M, Shimizu A, Motegi SI, Amano H, Ishikawa O: Successful treatment of lichen spinulosus with topical adapalene. Eur J Dermatol. 2015, 25:490-491. 10.1684/ejd.2015.2597

8. Lichen spinulosus in a young girl . (2014). Accessed: April 14, 2020: https://www.patientcareonline.com/view/lichen-spinulosus-young-girl.

9. Sobjanek M, Sikorska M, Sokolowska-Wojdylo M, Nowicki R: Lichen spinulosus. Przegl Dermato. 2014, 101:397-400. 10.5114/dr.2014.46070

10. Venkatesh A, Dupuis E, Prajapati V, Rao J: Generalized lichen spinulosus in a 4-year-old boy without systemic disease. Arch Dermatol. 2012, 148:865-866. 10.1001/archdermatol.2012.188

11. Seo JW, Sim HS, Choi JH, Lee SK: A case of lichen spinulosus arising at the site of antecedent seborrheic dermatitis. Korean J Dermatol. 2009, 47:868-870.

12. Kim CY, Park SY, Oh CW: A case of lichen spinulosus. Korean J Dermatol. 2008, 46:378-380.

13. Oh DH, Park KT, Kim JS, Yu HJ: A case of lichen spinulosus with an histologic finding of follicular mucinosis. Ann Dermatol. 2005, 17:79-82. 10.5021/ad.2005.17.2.79

14. Kim GN, Yu DS, Son SW, Kim AR, Kim IW: A case of lichen spinulosus. Korean J Dermatol. 2001, 39:1046. https://www.koreamed.org/article/0048KJD/2001.39.9.1046

15. Mittal RR, Kaur M: Lichen spinulosus. Indian J Dermatol. 1997, 42:42-43.

16. Kano Y, Orihara M, Yagita A, Shiohara T: Lichen spinulosus in a patient with Crohn's discase . Int J Dermatol. 1995, 34:670-671. 10.1111/j.1365-4362.1995.tb01115.x

17. Tuyp E, McLeod W, Boyko W: Lichen spinulosus with immunofluorescent studies. Cutis. 1984, 33:197-200.

18. van Santen S, Jansen PM, Quint KD, Vermeer MH, Willemze R: Plaque stage folliculotropic mycosis fungoides: histopathologic features and prognostic factors in a series of 40 patients. J Cutan Pathol. 2020, 47:241-250. 10.1111/cup.13615

19. Forman SB, Mac Hudgins E, Blaylock WK: Lichen spinulosus: excellent response to tretinoin gel and hydroactive adhesive applications. Arch Dermatol. 2007, 143:115-126. 10.1001/archderm.143.1.122

20. Kim SH, Kang JH, Seo JK, Hwang SW, Sung HS, Lee D: Successful treatment of lichen spinulosus with topical tacalcitol cream. Pediatr Dermatol. 2010, 27:546-547. 10.1111/j.1525-1470.2010.01275.x 